\title{
6
}

\section{CLIMATE CHANGE AND}

UNCERTAINTY IN INDIA'S

MAXIMUM CITY, MUMBAI

\author{
Hans Nicolai Adam, Synne Movik, D. Parthasarathy, \\ Alankar, N.C. Narayanan and Lyla Mehta
}

\author{
It is said that Bombay never sleeps \\ Never stops \\ Never tires \\ But brother, on Tuesday $26 \mathrm{July}$ \\ Bombay stopped \\ Bombay tired \\ Every mobile phone went silent \\ When the cloudburst struck Bombay \\ Darkness prevailed when the power went out
}

- A Bhojpuri music video called 'Museebat mein Bambai' describing Mumbai's mood following the $26^{\text {th }}$ July 2005 flooding

\section{Introduction}

In this chapter, we explore how climate change and uncertainty shape the urban landscape of Mumbai - a megalopolis whose land was largely reclaimed from the sea and that faces ever-increasing threats from climate change, environmental deterioration and development pressures (Figure 6.1). Globally, the city consistently ranks as one of the most threatened megacities from the effects of climate change (Hanson et al. 2011; Abadie et al. 2020), with flooding arguably one of the most formidable natural hazards it faces. In 2005, Mumbai experienced a traumatic and devastating flood event, the so-called Mithi deluge, which claimed more than 1,000 lives, in addition to causing enormous economic and property damage (Bhagat et al. 2006). Despite promises and efforts by urban authorities to transform Mumbai and prioritise flood mitigation in the aftermath of the 2005 event, flooding remains chronic with regular disruption, economic damage and loss of human lives occurring every year in pockets or affecting the 


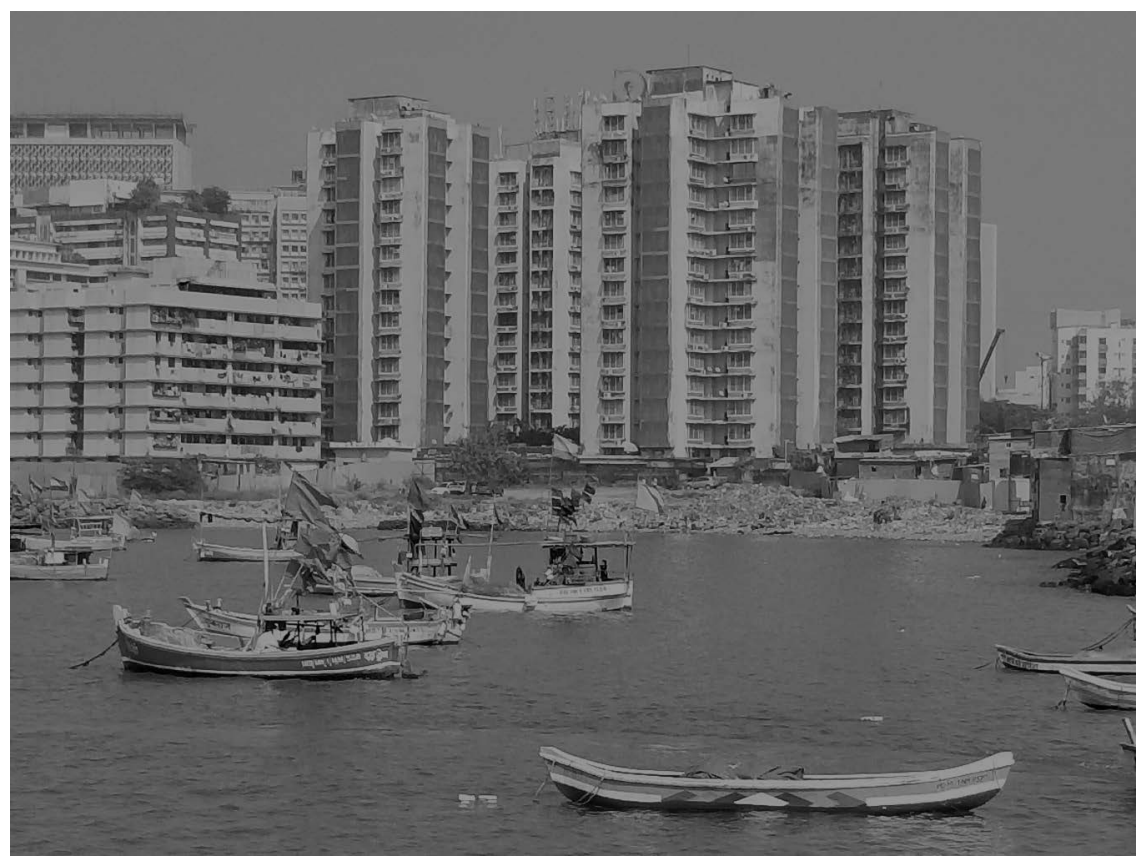

FIGURE 6.1 Koli fishers and urban expansion in Mumbai (Photo credit: Hans Nicolai Adam).

entire city. Multiple flood events continue to wreak havoc and have brought the central and suburban districts to a standstill for intermittent periods over the past years (see Kumar 2019; Singh 2020).

Flooding is, however, not a "natural" phenomenon attributable to climate change and rainfall alone. It also relates to the physical characteristics of the city's landmass, its built environment, urban governance as well as socioeconomic characteristics - and the growing uncertainties that accompany these interlinked issues. We explore these aspects by examining the nexus between urban development, political economy and the science-policy interface through the perspectives of the "above", "middle" and "below".

Flooding is not new to Mumbai. It is expected and "normal" to experience waterlogging, localised inundation and disruption to transport services on a seasonal basis - especially with the onset of monsoon rains. Flooding and climate-related uncertainties in the monsoon season are usually experienced within normal bounds, and as we document in this chapter, residents of the city have devised coping and adaptation strategies accordingly. Yet, rare "outlier" events have increased since 2005 - ranging from cyclone threats to droughts or extreme rainfall variations. For example, in July 2020, the city recorded its wettest month on record (Chatterjee 2020) with threats of the "worst cyclone 
in decades", Cyclone Nisarga in the same year, prompting the evacuation of tens of thousands of people (BBC 2020). Every year appears to bring about new climatic challenges, and in 2020, the pandemic was added to the mix. Thus, a new type of radical uncertainty is emerging that lies outside the bounds of what is regularly experienced - straining tried and tested coping and adaptation mechanisms, with implications for future urban policy and development.

What makes Mumbai so vulnerable? The coastal megalopolis is a complex urban landscape that represents a microcosm of the conflicts, threats, opportunities and uncertainties that global integration, economic growth, demographic transition and climate change bring forth. It is the financial capital of India and one of its largest urban agglomerations with a population of over 12 million people in its municipality (Census of India 2011) and an estimated 20 million plus in the metropolitan region. The increasingly dense built-up space in central and suburban Mumbai has diminished scarce open spaces that act as flood plains, limiting water percolation and leaving central areas of the city highly flood prone. Disappearing coastal wetlands, flood plains and poor disaster governance (Revi 2005, 2008) further heighten Mumbai's vulnerability to already chronic flooding. The destruction of mangroves in the city and its periphery has aggravated livelihood threats to the thousands of Koli fishers, the original inhabitants of the city, along the east and west coast (Chouhan et al. 2016). Nearly half of Mumbai's residents live in informal and temporary dwellings with limited provision of basic services such as clean water, education, sanitation and healthcare (de Wit 2016). Across the city, the most severely affected residents from flooding, and displaced by infrastructure projects tend to be poorer, socially excluded and are forced to live on marginal, low-lying land. Inadequate sanitation, solid waste management, poor governance and illegal construction activities compound threats from regular rainfall events and climate change to leave the city and its residents highly vulnerable (Revi 2005; Hallegatte et al. 2010; Ranger et al. 2011; Parthasarathy 2018).

In this chapter, we explore this vulnerability context and tease out the politics and perspectives around the (changing) nature and impacts from climate change and uncertainty in Mumbai. Our focus is particularly on the city's most vulnerable residents, who make up a heterogeneous mix of migrants, castes and religious minorities living largely in informality and threatened by the intersection of climate change, flooding and iniquitous development interventions. We argue that the dominant pathways of dealing with climateand flood-related uncertainties are exclusionary in nature and vie for control through structural measures, while not integrating alternative planning ideas or evolving climate change threats into urban governance and policy. The chapter proceeds as follows: we first briefly sketch out our conceptual framework, proceed to describe Mumbai's socio-economic profile, before engaging with the narratives, understandings and approaches from the "below", "middle" and "above" - informed by our ethnographic fieldwork - and end with a concluding discussion that presents our main findings. 


\section{Conceptual framework: uncertainty in urban Mumbai}

Climate mitigation and adaptation concern much of contemporary urban development planning and policy. Urban centres in the global South play a vital role in achieving climate targets because of their importance as population centres, drivers of economic growth, vulnerability to climate impacts and also sources of greenhouse gas emissions (While and Whitehead 2013; Heynen 2014; Kumar et al. 2020). The "mainstreaming" of climate priorities into development planning, urban governance and policy has concomitantly accelerated, albeit with mixed results that heighten the possibility of maladaptive action (Eriksen et al. 2021) and long-term climate risk integration into planning falling short in India's urban centres (Singh et al. 2021). How do we conceptualise our research in Mumbai with respect to these issues? Vulnerability studies underpin much of existing work on climate adaptation (Adger 2006), with different interpretations of vulnerability having implications for the way adaptation action is framed and practised (O’Brien et al. 2007). We go beyond understanding adaptation merely as a response to climate stimuli in a separated human-environment system. Instead, we understand adaptation as part of an existing vulnerability context that is premediated by socio-historic and scaled economic, cultural and ecological factors. We also respond to Ribot's critique of "locating causality within the hazard" (2014: 667), and the undue focus in the risk-hazard literature on proximate causes for vulnerability, which pays little attention to causality by sidestepping interacting socio-ecological processes that leave people vulnerable in the first place. In contrast, a more technically, natural science-informed framing of adaptation concentrates disproportionately on homogeneous, quantifiable limits and costs and benefits. Responses here concentrate on techno-managerial solutions that leave little space for differentiation and political contestation (O'Brien and Barnett 2013; Eriksen et al. 2021). As discussed in the Introduction and Chapter 2, despite the apparent limitations of dominant, quantitative methodologies and their efforts to vie for "control" through static, deterministic approaches (van de Sluijs 2005), they remain at the forefront. This is demonstrated by the disproportionate attention that technical measures receive in adaptation and resilience projects as well as "universalist" urban planning approaches (UNEP 2014; Zeiderman et al. 2015) that rely on centrally designed "master plans" as instruments to achieve a set of economic, social and political goals (Watson 2009).

Uncertainty, as we conceptualise in this book, is becoming an ever more important feature in climate and development debates in urban areas. Urban agglomerations form "cluster points" for various uncertainties to meet in a turbulent age of globalisation, migration, environmental change and technological upheaval (Zeiderman et al. 2015). These uncertainties fall into ontological and/ or epistemological categories (Walker et al. 2003) and as we distinguish in the Introduction, fall into ecological, knowledge/epistemic and political economy domains (see also Mehta et al. 2019). As discussed in the Introduction, uncertainty 
in climate change projections compound the problem for urban policymakers to formulate strategic responses in adaptation or mitigation realms. For example, to what height should storm surge barriers be built, based on what projections and at what location? Ecological uncertainties extend to those found in the knowledge realm. In the case of Mumbai, as we show, a pertinent example of aforementioned "knowledge politics" is the approach to "control" or "tame" flooding through the construction of boundary walls along the Mithi river and other drainage channels - prejudicing one knowledge regime over alternatives that might be anchored on local peoples experience but are deemed "unscientific". Uncertainties also extend to the political economy realm where they may be a product of social differentiation (gender, caste, class or ethnicity), historical or political arrangements. These warrant an exploration of the diverse range of institutions, processes and structures (climate-related and otherwise) that "modernist" urban planning approaches have so far largely bypassed (Watson 2009). Urban governance itself emerges here as a source of uncertainty, in conjunction with a confluence of social, political and economic uncertainties that intersect with ecological ones in intricate ways (see also Parthasarathy 2018). The location, origin and nature of uncertainty also differ depending on the kind of climate-induced impact one is studying and on the social actors that are the subject of interest.

We understand a transformation of this vulnerability context in broad terms according to Few et al. (2017), in the sense as adaptation that generates transformation as outlined in Chapter 1. In the urban context of Mumbai, this implies that social and environmental justice goals (equality, inclusiveness and participation), a co-production of knowledge that acknowledges plurality and incorporation of environmental values in planning and a departure from "business as usual development", would emerge as priorities. At the core of transformation lies a re-configuration of relative power dynamics that address the factors which enable vulnerability in the first place (lack of housing, gender and caste discrimination) and goes beyond strengthening of resilience, technical measures or disproportionate attention towards incentivising coping action (Ribot 2014).

\section{Methodology}

We used methodological tools and approaches that were ethnographic and qualitative in nature. These included transect walks, key informant interviews, group discussions, structured, semi-structured interviews and key event analysis. Snowballing was used extensively to locate key informants. Interview guides developed over the heuristics of the "above", "middle" and "below" were used to identify respondents, pose research questions and follow up on analysis. A cross section of respondents that are reflective of gender, class, polity, academia and bureaucracy was subsequently interviewed. These included several key government officials with the Mumbai Metropolitan Region Development Authority (MMRDA), Mithi River Development and Protection Authority (MRDPA), Brihanmumbai Municipal Corporation (BMC) - including its 
disaster management cell, Maharashtra Forest Department and Maharashtra Pollution Control Board (MSPCB) working on disaster and urban governance issues. In addition, professors and scientists from the IIT-B, Tata Institute of Social Sciences (TISS) and National Environmental Engineering Research Institute (NEERI) who have been involved in water, flood, development and disaster management planning were interviewed, as well as civil society figures from leading think tanks, environmental non-governmental organisations (NGOs) and civil society organisations (including Vanashakti, Observer Research Foundation [ORF], Mithi Sansad, fisher and residential associations). To protect the identity of respondents, their names and designation have been anonymised. In addition, a literature review covering policy documents, scientific articles, newspaper coverage, reports and other sources was conducted. Data collection by the research group took place during multiple field visits in the period from 2015 to 2020 covering different seasons. In total, more than 130 interviews were conducted, providing a rich data set. Where possible, interviews were recorded and transcribed; otherwise, detailed field notes were taken. Government reports, newspaper clippings as well as transect walks over the duration of different study periods were consulted in efforts to identify sites.

\section{Study sites}

\section{Maximum city Mumbai}

Mumbai, formerly Bombay, sits mostly on reclaimed land, in building efforts that date back to the 18 th century. The first settlers in this area were fishers belonging to the Koli community who now reside in 45 Koliwadas (fishing villages) spread across the nooks and corners of the greater metropolitan area. Bombay city itself grew out of seven islets, Colaba, Old Woman's Island, Bombay, Mazgaon, Parel, Mahim and Worli, which were connected over the years from inter-tidal zones to lay the physical foundation stone for the city. This process continued over two centuries and ended with the last major official land reclamation in the 1970s at the southern tip of Mumbai at Nariman point (Perur 2016) with unofficial reclamation continuing even now. Today, the city is composed of a contiguous $438 \mathrm{~km}^{2}$ landmass surrounded by the Arabian Sea, Harbour Bay and Thane creek on three sides. Administratively, Mumbai is composed of two parts, the island district to the south with the downtown area hosting the most densely populated parts and the suburban district reaching towards the inland.

Most of the city's landmass lies between 2 and $5 \mathrm{~m}$ "above" sea level, with some areas lying "below" the high tide mark (Hallegatte et al. 2010; Pramanik 2017). The most visible, "hard" manifestation of exponential, unregulated growth is the mushrooming of high-rise residential towers, transport infrastructure (e.g. flyovers, metro) which stand in contrast to poor public facilities, housing and deteriorating air and water quality - interspersed with spots of affluence found in malls and iconic public infrastructure projects such as the gleaming Mumbai 
international airport or the state-of-the-art Bandra-Worli sea link. Real estate in densely populated central Mumbai belongs to the most expensive in the world. An estimated 220 billion USD investment volume in civic infrastructure is required in the metropolitan area over the next 20 years alone to accommodate the needs of this growing city, according to global consultancy firm McKinsey (Thomas 2018). Many mega projects including the Mumbai metro, Navi Mumbai airport, the trans-harbour link and coastal road project are already being constructed in fits and starts despite legal obstacles.

Migration has historically played an important role in shaping the city's burgeoning informal economy, which provides for the bulk of employment. Migration has also traditionally been a source of inexpensive labour and contributes to the heterogeneous character of its population, attracting people from all states of India and beyond. In recent years, however, population growth in the central parts of the city has slowed, in part, because of overcrowding and higher rental prices but also because of employment opportunities in the suburban areas and changing demand for skills in response to established industries (such as tanning or textiles) either becoming defunct or relocating (de Wit 2016). Economic prowess combined with the diverse migrant community, relatively liberal culture and colonial history has produced a uniquely wealthy and cosmopolitan city boasting of the richest municipal body in India (de Wit 2016).

Mumbai is a city of stark contradictions and inequality with immense wealth, corporate power and poverty co-existing side by side, with slums and modern high-rises jostling for space just a few metres apart. The intense mix of people, economics and politics over a confined, dense and contested space led to the popularised label of "maximum city" (Mehta 2004). The city also has the dubious distinction of having the highest proportion of slum dwellers relative to the total city population in India with an estimated $40-55 \%$ of the population residing in such areas (Census of India 2011; Alexander and Bhatia 2020).

Population growth, land reclamation and economic development contributed to extensive alterations of the metropolitan region's biophysical environment. Mangroves play a role in reducing wave strength, soil erosion and provide ecosystem services important to reduce the effects from climate extremes and sealevel rise. They also play a crucial role in the livelihood strategies of vulnerable fishing communities in and around Mumbai, by providing safe sanctuaries and a breeding ground for fish. According to Vijay et al. (2005: 310), 50,000 Koli fishers are active in the region. There is competing demand on mangroves for various land uses in the city, and this has led to a $40 \%$ decline in mangrove cover between 1990 and 2005, despite protective legislation (Vijay et al. 2005: 310; Singhi 2015).

\section{Climate change in Mumbai}

Climate change is affecting the city in profound ways. As a low-lying coastal city built on reclaimed land, sea-level rise is one of the most notable threats and is estimated to lie between 2.5 and $3 \mathrm{~mm}$ annually at present (Pramanik 2017). 
Projections expect a further average rise of 30-80 cm by 2100 (TERI 2014) with a study (Larour et al. 2017) finding that glacial melt alone could account for a 15 $\mathrm{cm}$ rise in sea levels over the next century. Mangroves are specifically vulnerable to sea-level rise because of their location at the interface of the sea as "between 0.4-0.9 m 'above' mean sea level” (Ellison 1989 cf. Jagtap and Nagle 2007: 331; Vivekanandan 2011: 17). A recent study by McKinsey found that up to three million people will be severely threatened by a combination from sea-level rise, flooding and high tides by 2050 (Woetzel et al. 2020). Sea surface temperatures off the Arabian coast have already registered an increase of $0.32{ }^{\circ} \mathrm{C}$ per decade from 1985 to 1998 (Khan et al. 2004). Likewise, mean atmospheric temperatures have risen by $2.4^{\circ} \mathrm{C}$ (from 1881 to 2015 ; NASA 2015) and are projected to rise to $1.5-1.8^{\circ} \mathrm{C}$ by 2050 (TERI 2014). Heavy rainfall is a regular occurrence in this region during the south-west monsoon from June to September, with an average precipitation of $2420 \mathrm{~mm}$ per year. Changing climatic configurations will likely intensify rainfall variability (18\% rise in minimum and maximum precipitation) and tropical cyclones are expected to become more frequent (TERI 2014; D'Monte 2017). The occurrence of health effects ranging from an increase in vector-borne and communicable diseases to those related to heatwaves is also set to increase (TERI 2014).

\section{Politics and perspectives from the "above", "middle" and "below"}

Mumbai's population is highly heterogeneous and comprised of varied, oftentimes competing interest groups. As one of the most densely populated cities in the world and with a high concentration of wealth and extreme poverty in the central and flood-prone areas interspersed with fishing villages, the politics of the city are complex - even by the standards of a megacity. In the following section, we tease out some of the key experiences, perceptions and responses that respondents from the "above", "middle" and "below" have voiced with regard to climate change, urban development and flooding in relation to intersecting uncertainties.

\section{Climate change and uncertainty from "below"}

"Climate change" emerges as a multifaceted term among the residents of Mumbai. Its link to a global phenomenon is not always straightforward, with considerable uncertainty regarding attribution in an urban environment. For some respondents, it relates mostly to weather changes at a local level. According to a taxi driver in Bandra: "Earlier there was a familiar pattern of rainfall in Mumbai, but now it has become very erratic, for the last couple of years there has been very poor rainfall” (Interview December 2017, Mumbai). As discussed in Chapter 2, instead of perceiving climate change as a long-term phenomenon with distinct implications, local residents often perceive even wide-ranging temperature and 
precipitation changes as a local outcome of development activities. Growing population, urban mismanagement, a densely built-up environment, depletion of natural resources or vehicular pollution are often reference points to attribute environmental changes. Interviewed residents in most colonies along the Mithi riverbank and closely adjacent areas perceive the weather to have become hotter and less predictable. The intensity of monsoon showers was also observed to have changed when we interviewed residents in the commercial hub of Saki Naka (near the international airport). Additionally, people noted that ambient temperatures increased alongside a reduction of cooling sea breeze. In other densely populated and built-up areas, with few open spaces like Dharavi, these perceptions on experiencing increasing heat were particularly pertinent. A female shopkeeper in Dharavi highlighted how oppressive the heat has become alongside a reduction in "cooling winds". Yet, daily livelihood uncertainties usually eclipse those from climate change. These include inflation rates, access to affordable housing, water and other basic services, job security and the threat of communal conflict.

For upper-middle-class residents such as an elderly couple in Bhandra (West), the scientific and global dimensions of climate change are more relatable. Climate change is perceived here as a distinct phenomenon. Temperature and precipitation changes, glacial melting, flash floods, urban heat island impact and the spread of diseases find recognition. Climate change is, thus, part of an established, global discourse in addition to local environmental changes. On the other hand, a stronger emphasis hinges upon divinity and less on "pollution" with other sections of society when discussing climatic changes, including with the Koli community. The role of different climatic patterns and extreme weather (e.g. thunderstorms, cyclones) is also associated with supernatural phenomenon, over which there is little or no human control and influence.

Koli fishers interviewed in Mahim, Versova and Cuff Parade are intimately dependent on marine and coastal ecological systems and articulate a nuanced understanding of environmental changes. According to the Koli respondents, climate change manifests itself in the form of depleting fish catch and increasing uncertainty in interpreting weather signs. Nevertheless, the main reason cited for their livelihood uncertainty lies in Mumbai's unbridled and expansive growth where Kolis and Koliwadas (urban fishing villages) are turning into sites of conflict between powerful interests, including commercial trawlers, real-estate developers and conniving state actors. In addition, the immediate coast is suffering from pollution and depleting fish stocks on account of the double stresses of ecological changes and overexploitation (Chouhan et al. 2016). Kolis dominantly fish within an exclusive $12 \mathrm{~km}$ radius from the coastline, a zone reserved for small/artisanal fishers. Altered weather patterns and changed seasonal patterns have led to decline in the quantity of fish available in this radius although it is not a uniform opinion across sites. Yet, unusual changes in temperature over the land surface impact wind patterns and most respondents insist that there is a direct connection between weather conditions and fish stocks. The older 
generation reported that they had a good understanding of time and location of fish breeds - without technological aids like modern GPS/sonar systems. These traditional knowledge systems rely on reading weather signals, where not only wind but also astronomic signals such as a star constellation or the moon position help in predicting weather patterns. However, environmental changes have considerably reduced predictability, contributing to a new type of radical uncertainty. Fish movements have changed, and some species entirely disappeared or are reduced to negligible numbers. Rainfall intensity and patterns have also shifted. Prolonged periods of rain lasting up to two weeks were regular earlier, but this has reduced to intense downpours within a shorter span of timeto days/hours - with reduced wind speeds. Over the last 15 years, the cooling effects from monsoon showers and wind have also decreased according to a fisher in Cuff Parade who reported that extreme and memorable weather events such as cyclones are becoming more frequent.

\section{The certainty of flooding and uncertainty from development planning}

As discussed earlier in this chapter, flooding is a common occurrence in the city during the monsoon. However, one event stands out. The massive rains and floods in the last week of July 2005 (bada paani in local slang and also referred to as the $26 / 7$ event) that killed more than a thousand residents with nearly an entire years rainfall descended on the city within 24 hours. All respondents cutting across class lines - who lived in Mumbai during that time, remember it as a traumatic event and as an "outlier". While the livelihood loss was much more pronounced with poorer residents who lived in shacks and lost their entire livelihood, middle-class residents remember it as an event where they lost access to power, remained stuck in traffic, had to wade through water or escape from dangerous flood waves and faced health hazards. Yet, beyond this "extreme event", there exists a certainty around annual flooding and it is perceived as a not unusual event - despite damages and interruptions caused every year. In terms of impact, there is a differentiation between wealthier/middle-class residents who live in flat complexes (on higher ground or in higher stories) versus those who live directly adjacent to Channels/along the Mithi river and in shacks that can get washed away.

At the same time, while monsoonal rainfall is viewed to be natural and "certain", waterlogging is socially, politically and economically constructed. Haphazard urban development - building over water bodies, failure to increase the capacity of stormwater drains, changes to nallahs and streams/creeks and poor solid waste management practices were cited as key reasons in addition to inequalities in social and economic status. As a result, not all people or localities face similar levels or impacts from flooding - the intensity and effect is usually a function of a differentiated socio-economic status and location. Geography and terrain, municipal attention as well as people's collective involvement and 
power in maintaining or improving their immediate residential areas explain differential experiences. There is more certainty in avoiding flooding in areas that are on higher ground, for instance - but are also more expensive to live in.

In areas that experience regular inundation (e.g. in Saki Naka, Kurla or Dharavi), the chronic nature of flooding has prompted residents to resort to opportunistic coping measures. They told us that accumulated knowledge and the drawing on "lived memory" helps tide over regular flood events, with several anticipatory steps taken to manage and limit uncertainty. Following the 26/7 event, interviewed residents along the Mithi and its tributaries display a higher level of sensitivity to the river flow following heavy rainfall and undertake control exercises themselves. Disaster preparedness and warning systems are communitybased. Once a visible danger mark is exceeded (marked through drawn lines along walls or the flooding of key structures), residents quickly disseminate information through informal networks and take precautionary steps. Adaptation measures, that is, those that go beyond short-term coping, include the construction of doublestoried (popularly referred to as 1+1) structures - wherein valuables are stored and sleeping spaces are made available on the upper stories of a building - including for neighbours living in lower storied structures as documented in Indira pipeline colony. The normal flooding level is defined by marks on walls that lie within pre-defined uncertainty bounds. But were an "abnormal" flooding to re-occur outside these bounds, the only option is temporary relocation or evacuation. There exists little faith and expectation in early warning to have changed by state agencies: "in the 2005 flooding we saw the police running away shouting for others to follow...this was disaster warning at that time" (Interview March 2016, Mumbai). Residents also mention that some structural measures including higher boundary walls and the widening of channels have increased drainage capacities but not enough to stave off heavy monsoonal rainfall. Similarly, it was reported that increasing the boundary wall height in one area simply pushes the flooding onwards to other low-lying locations.

How do other residential areas fare? In pockets of middle-class and relatively wealthier areas, within Bandra (East) and adjoining Kurla Pipeline Road localities, low-lying areas are also flood prone and interspersed by densely populated slums, where prolonged waterlogging is not unusual. Places like Airlines Colony in Kalina are not as prone to floods over regular rainfall periods because structural measures like concretisation such as boundary walls and small steps prevent flooding. Similarly, in Kherwadi locality of Bandra (East), flooding is more of a concern because it is densely populated with slums and middle-class residential flats lying adjacent. Many residents from posh Bandra (West) mentioned that post-2005, residential complexes took up concretisation autonomously around compounds and roads within their premises. We were shown around different stretches with new concretisation to prevent even minor water accumulation, where wealthier compounds attempted to insulate themselves from waterlogging. A side effect of these uncoordinated and autonomous activities was to increase uncertainty, vulnerability and flood proneness for other colonies that might not 
have resources to institute similar measures or are even lower lying. This effort also showcases the extent to which a lack of municipal involvement (from ward level upwards), co-ordination and structural socio-economic inequality increase uncertainties for some while reducing them for others. Concretisation efforts are in addition blamed to contribute to the urban heat island effect and limit groundwater percolation (Fernandes 2019). The failure to undertake similar interventions in other public spaces within Bandra (West) is problematic, but not exclusive to this area. In affluent south Mumbai, rare waterlogging was experienced in 2020 after intense rainfalls. A respondent mentioned that "At this point, even people in South Bombay know what flooding is like now after all this" (Interview October 2020, Mumbai) and attributed it to misguided and intrusive infrastructure development in connection with the metro and coastal road project, in addition to climatic changes.

The contestation between mitigation and adaptation priorities, with the former dominating the city discourse, was evident during our fieldwork in the poorer localities. The prospect of forced dislocation of unregulated residential colonies along the Mithi river - in the name of flood mitigation - looms large and is one of the greatest uncertainties poorer residents face. Inextricably related to flooding is drainage and solid waste management, which is of common concern for all respondents. Respondents state that poorly managed drainage and callous mismanagement of solid waste creates serious problems for drainage flow, in addition to numerous health hazards. Muslim residents in colonies where they are in the majority expressed frustration that despite promises, the BMC does not collect garbage and they are in effect forced to use drainage channels to dispose of waste material/sewage - forcing the clogging up of channels as a result of neglect. In some of these areas, the household waste relates to the livelihoods they are involved in which are home based - for example, garment sweat shops. There is also uncertainty on which of these belong to household/industrial waste.

The flooding of 2005 and Mithi river have a clear relationship in the minds of Mumbai's residents. Yet, there is little uptake among those we interviewed (especially the middle-class) to stark warnings of academics and environmental activists with respect to the state's plans and actions of concretising and taming the river. Respondents expressed that city authorities need to ensure that issues like desilting, preventing sewage and pollution from entering the river, channelising and widening of natural rivulets like the Mithi are a must to prepare for future extreme flooding events. For some wealthier interviewees, who have travelled widely, examples of other large, flood-prone cities that draw on other solutions to mitigate flood risk are used to contrast what is happening in Mumbai. The same respondents insist that mangroves must be preserved to bear with cyclone events in the future and also improve the air quality of the city.

Flooding did not emerge as a main concern for the Koli fishers. Instead, their main livelihood uncertainties stem largely from the infrastructure projects that have encroached upon the coast, fishing grounds and mangrove land. At present, the coastal road project is the most important intervention around which Kolis 
are protesting against and which causes livelihood and ecological uncertainties. The project to construct a $29.2 \mathrm{~km}$ long freeway from north-south Mumbai on its eastern coastline has been mired in legal conflicts and temporarily stalled before resuming work in 2020. A fisher we met at a public hearing on the project in Khar Dhanda in 2020 called the project out for "finally putting an end to the remaining fishing in our Koliwada" (Interview January 2020, Mumbai) because of the land reclamation along the coast, destruction of boat landing and fish breeding grounds as well as effects on coastal currents through the building of giant stilts that support the freeway. At the same public hearing we attended, the coastal road project and its planning were cited by a group of female activist's as emblematic of the lack of acknowledgement of Koli livelihood rights, sensitivities for coastal ecology and the top-down nature of project implementation. Despite petitions, protests and promises to take action on their behalf, construction on another mega project - the coastal road continues on core harbour and fishing grounds of the fishers along the eastern coast - creating immense livelihood uncertainties and also having implications for the city's ecology. There is also a clear gender bias in the impacts and uncertainties, with women from the fishing community loosing space and income for their shore-based livelihood activities that include pre- and post-harvest preparations.

\section{Views from the "middle"}

\section{No uncertainty here: the flood-prone city}

Considerable uncertainty exists regarding why exactly the city is so flood prone, how far climate change is responsible and what the way forward is. Many of the interviewees agree that cause and effect here are subject to complex interactions that include climate change but are not limited to it. One commentator employed at a prestigious social science institute when prompted on the uncertainty of flooding stated that:

Mumbai is a city of seven islands, with 66 villages on either side. Mumbai was marshy land and all surrounded by water. Lot of land has been reclaimed. It was certain that flooding was going to happen, and it's not an unexpected event.

(Interview May 2016, Mumbai)

The commentator elaborated, in line with other respondents, that activities to stem flooding are mired in controversy, delayed and suffer from planning uncertainties. Over the past 20 years, most planned activities (88\% according to the respondent) have never been implemented, which partly explains the city's vulnerability to flooding. The research director of an institute asserted that "basically the State itself, in the case of Mumbai, gave up on the idea of planned development" (Interview May 2016, Mumbai). Recommendations from comprehensive studies 
and committees like the Chitale committee report ${ }^{2}$ (2005) have barely seen any or only piecemeal implementation. Similarly, the BRIMSTOWAD (Brihanmumbai Storm Water Drain System) project has seen the completion of only 38 out of 58 planned projects in the past 14 years (Singh 2020). Several interviewed academics attribute the lack of resolution in completing construction activities to the lack of resolve on the part of the bureaucracy, red-tape, corruption and "vote bank" politics that protect illegal settlements and structures, thereby obstructing water discharge from stormwater drains and the Mithi river. The solutions to stem flooding and uncertainty by controlling it through engineering mean, for example, retainer walls, pump stations and the deepening of the Mithi river, are not perceived as problematic, especially by academics who are influential in proposing and designing policy solutions.

An academic working on disaster management mentioned that since the 2005 deluge, capacities to deal with flooding have increased and improved. The expert noted that from $225 \mathrm{~mm}$ of rainfall that could be drained, the capacity has now increased to $450 \mathrm{~mm}$, increasing the uncertainty bounds - but not sufficient for extreme events on the scale of 26 July 2005, where $946 \mathrm{~mm}$ of rainfall was recorded over 24 hours. Disaster response mechanisms underwent similar reform by improving response time, co-ordination between civic agencies and expanded emergency capacities. The NDRF (National Disaster Response Force) controls equipment (e.g. boats), manpower and other resources located in Goregaon (suburb in Mumbai) that can be quickly deployed to respond to severe flooding or other disaster events. Engineering solutions themselves are not perceived as problematic by a section of "middle" respondents. However, another expert, when prompted on the solution lying in techno-centric measures emphasised with respect to giant pump stations being constructed at multiple locations (e.g. Juhu) that "Pump stations...where do you take the water and where do you put it? Tides push the water back into land!" (Interview May 2016, Mumbai). A recent study (Fernandes 2019) confirmed this assessment which noted that only six of the 186 drainage outfalls to the sea are "above" the high tide mark, which is when the worst flooding occurs. Mumbai's geographic features are not suitable and sustainable for this kind of intervention of forcing drainage out to the sea.

The conflict between removing informal settlements - being a key livelihood uncertainty for the "below" - and "reclaiming" natural drainage space along the Mithi river as weak as other drainage channels and spaces is acknowledged but proves to be a contentious issue. What about these underlying root causes related to "encroachments"? The historic influx of poorer migrants and pressure on already scarce land is a reason cited for the proliferation of obstructive settlements and flooding. In contrast, a social scientist elaborated here that housing and the multi-generational nature of family units which requires long-term planning is totally ignored and contributes to the constitution of officially labelled "slums" or "encroachments", including in sensitive wetland areas. Most people from the "below" in Mumbai work in the informal sector and provide low-cost labour, 
with their location in the central areas essential to provide low-cost services. This is largely unacknowledged in the mainstream discourse.

The middle class is reacting to an informalised settlement, with which they are not in sync. Their aspirations of the city is basically in terms of a city which services them... The middle class today, in a city like Mumbai survives on the poor.

(Interview May 2016, Mumbai)

The lack of concern to provide safe and affordable housing for economically marginalised people is an important but often ignored factor in flood proofing and adaptation. Here, social justice and equality tie in with livelihood- and flood-related uncertainties. From an urban perspective, the "invisibility" of the informal sector became "visible" in the aftermath of the COVID-19 outbreak in 2020 when many migrants left urban areas. In the aftermath of this distress migration, labour for various services was lacking (from domestic workers to factory workers) and caused temporary supply chain disruptions. An environmental activist substantiated that while there are often complaints about informal settlements, residential towers for middle-class and upper-middle-class sections are aggressively built and encroach on fragile lands, including mangroves or wetlands and face much less opposition vis a vis informal settlements.

Regarding the iniquitous development approach, the state has also reneged on its obligation to allow for participatory planning and delimited opportunity structures for shaping development discourses and imaginaries. Planning horizons of government and state agencies tend to follow short cycles and are influenced by electoral considerations - creating significant institutional uncertainties (Interview May 2016, Mumbai), in the words of a researcher in a leading academic institution.

...since the 90s the government has really been engaged with project planning and keeping things away from the public, plan the way which was public but not participatory and in doing projects one is basically taking them out of the public space. ${ }^{3}$

This stands contrary to the devolution of localised planning directives under the 73rd constitutional amendment (1992/1993). Another prominent activist working on environmental issue for more than two decades substantiated that the proposals by the respondent and likeminded people have been met with neglect and largely ignored.

They call me anti-development... on every issue I have protested and raised awareness [waste dumping, mangrove destruction] I have provided an alternative solution...but no one listens or incorporates the alternatives. Instead, politicians and bureaucrats are influenced by the building mafia and money power 
The view of being labelled anti-development for providing alternative solutions or questioning certain projects was frequently cited by other social and environmental activists as well as critical academia.

\section{On institutional uncertainties and mangroves}

The lack of addressing basic, civic issues like sewage discharge figures prominently in the discourse around flood uncertainties. As a respondent noted, "Sixty per cent of the populations sewage comes straight into the river" (Interview May 2016, Mumbai). Therefore, drainage channels are chocked up and prevent discharge of excess surface water. While efforts to clear possible chocking points exist, institutional infighting and uncertain jurisdiction pose challenges. "Contractors are only given contract to remove silt. There is an institutional issue as to who is responsible for clearing the nallahs. The Indian railways says that it is the BMC [Brihanmumbai Municipal Corporation] and vice versa" (Interview May 2016, Mumbai). This does not mean that no efforts have been undertaken, but jurisdictional overlaps and boundaries complicate planning and sustainable outcomes. As a governance researcher from a think tank noted:

MMRDA [Mumbai Metropolitan Region Development Authority] makes one plan, BMC makes another plan. MMRDA is with state and BMC with city...if there is different political parties in power with MMRDA/BMC blame game ensues. Other important stakeholders in the planning process that have confused co-ordination are Indian railways, Port trust, CPWD [Central Public Works Department].

(Interview May 2016, Mumbai)

A simple measure like cleaning drainage channel does not happen regularly, what could and should be done every 15 days happens only once a year according to the same respondent.

The responsibility for mangroves is characterised by a similar process of institutional uncertainty with several departments involved in their management (e.g. fisheries, forests, revenue). Some of this uncertainty ensues because of ecological uncertainties related to the dynamic nature of mangrove growth and expansion into areas where they were not found previously. Ecological knowledge and political-economic uncertainty intersect here at multiple scales and provide a backdrop for contentious debates. Most "middle" respondents agreed that mangroves play an important role in flood mitigation and climate change adaptation. However, an engineering expert highlighted that mangroves are a controversial topic and questioned their role in flood mitigation "they are more useful in protection against tsunamis...but obstruct tidal movement and water outflow". Other respondents across academia and think tanks opposed this view and pointed towards the protective qualities they provide against a range of natural hazards. It is precisely for these properties (pollution control, 
coastal erosion, tidal buffers, ecosystem services) that they require conservation and protection. Mangrove conservation is also interlinked with questions around livelihoods and housing.

Migrants and poorer sections of society settle on "open" wetlands because of the lack of alternative cheap housing. Mangroves are subsequently destroyed and displaced. As a social science researcher highlighted: "policy for low-cost housing should be implemented. Delhi has shelters, why not Mumbai? Also protects the forested/protected area". Effective social policy becomes a harbinger of better ecosystem protection and flood mitigation in this narrative.

Some environmentalists tend to take a different view. For them, preserving mangrove ecosystems is essential if Mumbai is to survive in the long term. They emphasise the ecological value of mangroves and importance for climate change mitigation and adaptation, citing scientific studies for the same and see in it a struggle of "environment vs people". The best flood control measure is then to restore the Mithi river and surrounding wetlands to a "natural state" with inherent self-healing and regulating properties.

The Mithi is the most important flood control in the city and if the river is to be saved it needs restoration. look at it now and you don't even recognize it as such' and 'walling the river is a nonsensical solution.

(Interview April 2016, Mumbai))

What the environmental activists lament is a dilution of protective law and insufficient enforcement of existing statutory wetland regulations. Quite contrary to the way, other actors perceive the "biopolitical" creation/use of law and its anchoring in a politics for control. Another prominent environmentalist substantiated that the BMC, MMRDA and CIDCO (City and Industrial Development Corporation) ${ }^{4}$ instrumentalise scientific and institutional uncertainties around mangroves by claiming that they are a cause of flooding and justify land conversion exercises accordingly. Money power and greed are the driving forces for the strategic capture of fragile lands according to many interviewed "middle" actors. Fighting court cases to steer/shape development outcomes - especially by NGOs appears in the short term to be the main avenue of resistance according to respondents.

\section{Transformative pathways and climate change}

How has the city so far dealt with the issue of climate change? Most respondents, especially NGO members, paint a rather stark picture of apathy and missed opportunities. According to a prominent social activist:

I was part of the first panel discussion on climate change... if we were to run through some of the key decisions of the government in the past few years, they do not align themselves with either adaptation or mitigation at all. 
An NGO leader and lawyer, when talking about the Mumbai metro project, questioned whether it will be able to operate once flooding aggravates due to higher sea levels and more intense rain. Mega infrastructure projects of this nature are also considered to contribute to flooding by obstructing the outflow of water to drainage channels and the sea. Other interviewees did not see evidence of an integrated planning approach that is climate friendly and integrate climate risk into planning decisions. For instance, instead of expanding a pedestrian and cycle friendly city with more green and public spaces, the emphasis appears to promote mostly personalised, motorised transport. A leading urban planning and transport expert, in the context of the coastal road project, stated that there is a strategic effort to silence legitimate concerns by affected communities, while increasing ecological uncertainties of its fragile coast and accentuating socio-economic inequalities by promoting transport for the wealthier middle-class (Interview January 2020, Mumbai). All respondents perceive adaptation activities following the 2005 flooding as "incremental" and don't see evidence of any kind of transformation. "In 2016 if we're still seeing fires, still seeing the same amount of waste going to dumping grounds, clearly the system has not learned anything" (Interview May 2016, Mumbai). However, the identification of causality for this vulnerability differs. For one, underlying problems appear to lie in fundamentally skewed growth trajectories that are at the heart of carbon-centric industrialisation, neo-liberal growth paradigms and the climate crisis - all generating massive uncertainties that the city is finding increasingly difficult to manage "industrialisation and urbanisation are false concepts...climate change is a symptom and we need to return to a nature friendly, community based lifestyle" (Interview October 2017, Mumbai). This is a rather extreme view but supported by a person employed in a major multinational company and active in the same NGO. Other environmentalists also hinted at the same issue. Respondents said that some climate change impacts are obvious and not so uncertain. Mumbai is a sinking city, with climate change-induced sea-level rises likely to swallow parts of it in future. Not acknowledging this "scientific fact" and longer time horizons in planning will be disastrous. A lawyer and activist at the forefront of many legal struggles in the city added that a relocation of parts of Mumbai further inland is a necessary transformative option in the long run and must be explored. At present, however, few respondents saw transformative changes on the anvil. Recourse to judicial mechanisms was, in contrast, often quoted by respondents as more realistic option to galvanise or restrict projects, and there is a need for "judicially related reports to be fully implemented".

The head of a fisher's co-operative society in Versova painted a stark picture of the prospects for the fishing community. According to him "in 10 years' time, there will be no fishing community here" (Interview April 2016, Mumbai). The pressures from ecological (including climatic changes) and political economy uncertainties, such as climatic changes and changing aspirations among young people pose excessive stress and don't leave enough opportunities for the 
continued existence of the Kolis in the heart of Mumbai. Already today, out of 600 members in the co-operative, only 50-60 fishers regularly use their 12 boats. Another fisher representative from Cuffe Parade provided a more complex narrative. He mentioned that while young people face livelihood uncertainties and struggle for gainful employment in the fisheries sector, they are interested to take up rights and economic issues through new media and technology. Livelihood uncertainties stem mostly from development projects like the Shivaji statue, coastal road project and large trawlers that compete on unequal terms with local fishers. Within the dynamics of the city, the fishers have a sense of powerlessness against large corporate entities and conniving state power. Despite promises and protests, their concerns regarding infrastructure interventions have not been heard. Young people, because of the multiple uncertainties in traditional professions, seek alternative employment in the service sector that provide a more certain income...but still retain a "fisher identity".

\section{Views from "above"}

\section{Climate change is a certainty}

All the respondents from the "above" acknowledged that climate change is a reality, albeit with contested ideas on the influence and role that climate science and modelling has at the local level and especially in a built-up urban space such as Mumbai. More details on the views of scientists interviewed will be covered in detail in Chapter 2. A senior official with the MMRDA and MRDPA was clear in his assessment that today's urbanisation and climate change pose unique challenges but added that the government is already taking responsive steps, especially on the mitigation side. Mitigation policy options that focus on reducing carbon intensity in industries, increasing energy efficiency (e.g. LED lamps) and planting more trees on the lines of the "smart city" narrative was emphasised. The MMRDA is active in promoting green building codes and transport options, be it the new metro project, solar roofs on government, private buildings or water harvesting technologies. However, the "government can only do so much", community-level involvement and behavioural change are key aspects to change in addition to private initiatives. Educational institutions are important to reach younger people, build awareness and motivate participation, that is, through cleaning their neighbourhoods and not throwing garbage into channels. This ties in with the need to anchor climate issues within an everyday context "everyday living is a priority not global change". Another senior official with the disaster management cell added that in response to a variety of natural hazard threats the government has initiated steps to increase disaster response capacities, including those stemming from global climatic changes. Low-cost technological options were also emphasised by a MSPCB official as being pivotal to achieve mitigation targets. Specifically, technology transfers from the developed world are required in the absence of resources and know-how. 


\section{Controlling floods and the role of mangroves}

How does the "above" relate to uncertainties surrounding flood control and mangroves management? With respect to flooding, a senior official from the MRDPA added that "flooding in Mumbai is not an uncertainty, it is a certainty" (Interview April 2016, Mumbai). However, attributing rainfall as a causality is a key problem when framing the planning discourse around flood proofing. It acts as a diversion from addressing real issues by a host of actors. Flooding "is a result of high tides, rainfall, encroachments, sedimentation, concretisation and the urban heat island affect as well as infrastructure projects such as the Mumbai airport" (Interview April 2016, Mumbai). However, the official substantiated that since 2005, the BMC and MMRDA have undertaken a number of steps to protect the Mithi river and allow for greater flood proofing. It was conceded that despite marginal improvements no transformative change has taken place. What solutions exist? There are "no soft solutions for hard problems, hard solutions are required". This implied freeing adjacent land around the Mithi from illegal encroachments and strictly enforcing legal regulations around land usage. In connection, it was acknowledged that dilemmas and uncertainties exist; especially with trade-offs that revolve around housing and jobs. Solutions need to be found nevertheless in conjunction with rehabilitation, and this can only be achieved with civil society participation. It was also noted that environmental variables still do not figure actively in planning narratives, including with climate change policy, a point that needs improvement and a change in governance procedures. Actionable steps on how this can be achieved were, however, not forwarded.

According to a respondent who was a senior engineering consultant to flood mitigation projects in Mumbai, "The Mithi flood wall is based on experiences from other cities", pointing out that such interventions have worked elsewhere (i.e. in Singapore). The consultant added that the "government comes to us [scientific institution] to seek advice on flood mitigation however there is no continuity in governance". He added that "science itself is not at fault, however it is not used for the people, we need good science and good scientists" (Interview April 2016, Mumbai). As to the ineffectiveness of the engineering solutions to prevent regularly occurring inundation, the engineering expert substantiated that "our science is not at fault and the engineering structures work" (Interview April 2016, Mumbai). Instead, the onus with respect to the lack of proper implementation and outcomes is placed on governance and political uncertainties that prevent a translation of knowledge into practice. Based on political exigencies (e.g. bureaucratic appointment to key positions being a highly sensitive exercise), key personnel in the urban planning sections of the BMC or MMRDA are shunted out from office before their terms expire or are replaced by bureaucrats with very different expertise and approaches. In turn, this prevents continuity in governance and harms the implementation of flood control and mitigation projects.

An interviewee at the BMC disaster management cell highlighted that "response capacities to flooding have considerably improved and we can react 
now within a very short time". While flooding on the scale of 2005 is not preventable, regular flooding does not pose a major hurdle in terms of disruptive potential. ${ }^{5}$ The BMC disaster management cell is well networked and makes extensive use of technology to quickly receive information, for example, from the IMD (Indian Metrological Institute), which is then processed, civic agencies alerted and response activities quickly levied to address any physical disruptions (fallen trees, electric shutdowns, rescue, etc.). These capacities did not exist in 2005 and signify a transformation within disaster management, combined with a better management of uncertainty. The use of modern information and communications technology, like smart phone apps also provide early warning and helpful tips to every citizen on how to behave during a disaster event. The caveat being that the respective app has been downloaded only a few thousand times. The official also pointed out how important it is to be quick and efficient in disaster response in a city such as Mumbai.

"If there is disruption in services it creates a political storm, even regular maintenance disruptions is a major issue". He, however, conceded that flood mitigation itself has not been very successful. "There is priority towards actionable, immediate interventions that allow the city to function [without any long term planning] ... Mumbai is so complex, with so many interests it is very difficult to...take right steps" (Interview January 2017, Mumbai).

On the matter of sewage and obstruction to the Mithi river flow, an official from the MSPCB asserted that "The cleaning up of the river doesn't require any rocket technology, it's a very simple one, to prevent the sources, that is the minimum requirement" (Interview April 2016, Mumbai). He also asserted that most of the polluting industries have been shifted away and "Mumbai it doesn't have a problem of the industry, it's the problem of the residential solid waste". This is on account of traditional industries such as textiles increasingly having shifted outside of central Mumbai.

A departmental engineer at the BMC described the steps taking to install pumps, barriers and construct concrete walls in areas that were flood prone. The engineer stated that these interventions were designed according to rainfall data, inundation areas and vulnerability maps and prevent recurrent flooding. All interviewed actors agreed that collaborative efforts at the community level are required for successful adaptation and better disaster preparedness to be achieved but did not provide concrete steps on how such participation and collaboration can be achieved that will improve on existing processes. The Mumbai Development Plan 2034 was referenced by some "above" and "middle" actors as a positive initiative, receiving widespread input from various civil society groups and citizens, yet it was also criticised by activists who pointed to the lack of locationspecific flood planning, a focus of the plan on maximising construction heavy built-up environments and ignoring climate change concerns (Joshi 2019).

A bureaucrat with the mangrove cell explains that the strategic capture of mangroves by the building mafia and "slumlords" remains an issue. Also, debris from construction activities and dumping are problems. However, the department 
has been active to fulfil its mandate to prevent encroachments and "4000 illegal hutments in Mumbai were demolished on encroached land" (Interview January 2017, Mumbai). The mangrove cell, constituted in 2012 to consolidate governance among different departments (forest, revenue, fisheries), has emerged as a model for combining livelihood/community and conservation activities according to the respondent. In the Mumbai region, 5,400 hectares alone are classified as mangroves and they have increased in coverage over the past few years. In the Thane creek (around Uran), there is no threat to mangroves, and in general, "the situation is better than reported now a days", with increased public education, awareness and protection. Only 12 hectares of mangrove patches are under imminent threat. In Navi Mumbai (airport development) and the transharbour link in Mumbai, where mangroves had to make way for development projects, "blood money" had to be paid by the actors involved, those funds (186 INR crore) flowed into the establishment of a mangrove trust that pays for compensation, conservation and rehabilitation of people and forests across the region. Similarly, for small farmers, "mangroves are a curse", as their land become valueless, don't allow for agrarian activities and invite state involvement. This private-public partnership could be a model for the future. At the same time, the official remains sceptical of other infrastructure interventions and expresses a sense of powerlessness against interests that push giant infrastructure projects like the coastal road project.

\section{Concluding thoughts}

In this chapter, we engaged with the narratives, understandings and approaches of the "below", "middle" and "above" in the urban context of Mumbai and the various interlinked uncertainties that the city and its people confront. As we illustrate, substantial differences exist in the way that actors from the different heuristic categories (and sometimes within) understand, experience and respond to uncertainties arising from flooding, climate change and development interventions. We uncovered the deeply unequal nature in which these uncertainties are distributed, with poorer and marginalised sections of the "below" being the worst affected people in the city, having to confront a confluence of livelihood and ecological uncertainties. These include, in particular, Koli fishers facing existential threats from the construction of exclusionary development projects such as the coastal road zone project and suffering from dwindling fish stocks as well as migrants and poorer people residing in informality along the Mithi river and similar areas living in constant fear of eventual displacement and flooding. We also highlighted the complexities and uncertainties that exist in Mumbai when tackling issues of flooding and climatic change.

Climate change as well as issues around its attribution emerge as a nuanced and socio-economically differentiated phenomenon. For most interviewed respondents, climate change manifests itself through changing rainfall patterns, increasing heatwaves and powerful winds. While for the middle-class, there is 
a tenuous connection to the scientific conceptualisation of "climate change", this is not so much the case for poorer residents living in informal settlements in central Mumbai. They also point to pollution, the built-up environment, loss of green spaces and divinity for the more extreme weather and climate shifts. For marginalised Koli fishers, on the other hand, the effects are most pronounced with their traditional knowledge systems increasingly becoming obsolete, unable to adapt within short time spans to climatic and ecological alterations. Fish grounds have also shifted or are depleted although this is mostly linked with pollution, damage to marine ecology and unsustainable fishing practices by large trawlers.

Repeat flooding events over recent years illustrate how endemic the nature of flooding remains and is likely to aggravate in future with climatic change becoming ever more pronounced - be it through sea-level rise or extreme variations in rainfall. In 2020, even the wealthiest parts in south Mumbai, which mostly escapes flooding, were hit. Flooding in low-lying areas around the Mithi river has come to be expected and normal, especially during the monsoon season, but constitutes a source of episodic uncertainty for the "below", which has been met with local and autonomous adaptation action that is usually not coordinated with state planners or institutions (e.g. concretisation around flat complexes) and hits the poorest people the hardest. While disaster response efficiency appears to have improved, little progress has been made on flood mitigation. Much of this lack of progress was also attributed to insufficient long-term planning, where climate and flood risks are actively considered in planning prerogatives and incorporate local realities (geographic and socioeconomic). The increasing incidence of extreme weather events also signals the emergence of an era of radical uncertainties that urban planners will have to confront. Existing policy frameworks, including the Maharashtra State Action Plan on Climate Change, Mumbai's National Disaster Management Plan or Mumbai's Development Plan 2034, have fallen short to incorporate long-term climate risks, focusing instead on mitigation action, short-term responses or economic growth maximisation.

Adaptation interventions are heavily informed by "above" actors and overwhelmingly directed at structural improvements that are more amenable to dominant pathways of decision-making, embedded in the political economy of the city, its governance regime and rely on technical measures. These are interventions that seek to control flooding through concretisation and various engineering solutions. The "middle", civil society activists and some academics feel sidelined in deliberations around flood control planning and highlight how their alternative suggestions are routinely bypassed. This does not mean that no improvements have taken place. Retainer walls have been built, drainage capacity increased and pump stations built. Yet, all these interventions fall only within the coping realm, in fact, often creating new spots for flood uncertainties to emerge as "below" respondents reported. Structural interventions, including the construction of pump stations, also fail to take into consideration Mumbai's unique geography with respondents from the "middle" 
highlighting the tenuous physiography, low-lying city and sensitive ecology that surrounds Mumbai. Governance approaches in Mumbai remain fractured with central, state, urban and local agencies unable to effectively coordinate, network or jointly create more inclusive and long-term planning alternatives. This institutional uncertainty was pointed out by all heuristic categories as a key issue that prevents planning and proper execution of urban development projects, including for flood mitigation.

We, thus, see that urban governance and development modes in Mumbai are driven by a desire to control and follow universalist planning modes, with insufficient capacities to acknowledge and incorporate uncertainties, plural perspectives or incorporate the concerns of its most vulnerable residents. What could be a way forward? A shift towards a plural perspective is a precondition for the city to transform from its current state of vulnerability and address multiple, intersecting uncertainties in a more sustainable and equitable manner. This would also allow for more communicative planning that draws on multiple knowledge regimes and actors, involves participatory planning exercises, better integrated and coordinated city and regional planning, a prioritising of public goods and services, and a continued sensitising of the public and officials towards ecological and civic realities. As Edelenbos et al. (2017: 15) observe, urban development "cannot be controlled and steered from one point ... and needs efforts to collaborate rather than efforts to control". A shift in Mumbai's exclusionary approach of urban governance and development is, thus, much needed and key when addressing the multiple, intersecting uncertainties, including from climate change, that confront the city and its most vulnerable residents.

\section{Acknowledgements}

The authors would like to thank the IIT research assistants and scholars Abhiram Sarahsabude, Sagat, Nandankumar, Suddhawati and Hemant Chouhan for sharing their expertise, time and patience. We would also like to thank the anonymous respondents for their active participation, insights and time when carrying out this research.

\section{Notes}

1 See: https://www.youtube.com/watch?v=-RM_Kh4NbSg\&ab_channel=Ultra Cinema.

2 The Chitale committee report, accepted by the government, pointed towards encroachments along riverbeds and basins, land use conversion and waste dumping for flood proneness.

3 Agency formed by the Government of Maharashtra tasked with urban development duties

4 Interview conducted before 2 major flood events in autumn 2017.

5 In 2016, before the monsoon, these were promised to prevent substantive inundation. However, on visiting these areas during the monsoon they were heavily inundated. 


\section{References}

Abadie, L.M., L.P. Jackson, E.S. de Murieta, S. Jevrejeva, and I. Galarraga. 2020. 'Comparing Urban Coastal Flood Risk in 136 Cities Under two Alternative Sea-Level Projections: RCP 8.5 and an Expert Opinion-Based High-End Scenario'. Ocean \& Coastal Management, 193: 105249. https://doi.org/10.1016/j.ocecoaman.2020.105249

Adger, W.N. 2006. 'Vulnerability'. Global Environmental Change, 16(3): 268-281. http:// dx.doi.org/10.1016/j.gloenvcha.2006.02.006

Alexander, S. and S. Bhatia. 2020. 'Mapping Mumbai's Slum Challenge in Coronavirus Battle'. The Live Mint, New Delhi, 9 April 2020.

BBC. 2020. 'Cyclone Nisarga: India's Mumbai Escapes Worst Cyclone in Decades'. BBC, London, 3 June 2020.

Bhagat, R. B., M. Guha, and A. Chattopadhyay. 2006. 'Mumbai after 26/7 Deluge: Issues and Concerns in Urban Planning'. Population and Environment, 27(4): 337-349 https://doi.org/10.1076/iaij.4.1.5.16466

Census of India. 2011. 'Cities Having Population of 1 Lakh and Above'. Available at: http://censusindia.gov.in/2011-provresults/paper2/data_files/India2/ Table_2_PR_ Cities_1Lakh_and_Above.pdf (accessed on 5 March 2019).

Chatterjee, B. 2020. '2020 Monsoon is Mumbai's Second Wettest in 10 Years'. Hindustan Times, New Delhi, 13 September 2020.

Chouhan, H.A., D. Parthasarathy, and S. Pattanaik. 2016. 'Coastal Ecology and Fishing Community in Mumbai'. Economic and Political Weekly, 51(39): 48-57.

D’Monte, D. 2017. 'Cyclones will Cause More Cyclones in Arabian Sea'. Available at: http://indiaclimatedialogue.net/2017/12/20/climate-change-will-cause-morecyclones-on-arabian-sea/ (accessed on 9 June 2018).

De Wit, J. 2016. Urban Poverty, Local Governance and Everyday Politics in Mumbai. New Delhi: Routledge.

Eriksen, S., E.L.F. Schipper, M. Scoville-Simonds, K. Vincent, H.N. Adam, N. Brooks, ... and J.J. West. 2021. 'Adaptation Interventions and Their Effect on Vulnerability in Developing Countries: Help, Hindrance or Irrelevance?'. World Development, 141: 105383. https://doi.org/10.1016/j.worlddev.2020.105383

Fernandes, S. 2019. '70\% Rise in Concretised Surfaces Increased Flooding in Mumbai: Report'. Hindustan Times, New Delhi, 25 September 2019.

Few, R., D. Morchain, D. Spear, A. Mensah, and R. Bendapudi. 2017. 'Transformation, Adaptation and Development: Relating Concepts to Practice'. Palgrave Communications, 3. https://doi.org/10.1057/palcomms.2017.92

Hallegatte, S., and J. Corfee-Morlot. 2011. 'Understanding Climate Change Impacts, Vulnerability and Adaptation at City Scale: An Introduction'. Climatic Change, 104: 1-12. https://doi.org/10.1007/s10584-010-9981-8

Hallegatte, S., N. Ranger, S. Bhattacharya, M. Bachu, S. Priya, K. Dhore, F. Rafique, P. Mathur, N. Naville, F. Henriet, and A. Patwardhan, K. Narayanan, S. Ghosh, S. Karmakar, U. Patnaik, A. Abhayankar, S. Pohit, J. Corfee - Morlot, and C. Herwijer. 2010. 'Flood Risks, Climate Change Impacts and Adaptation Benefits in Mumbai'. Environment Working Paper, No. 27, Organisation for Economic Co-Operation and Development, Paris.

Hanson, S., R. Nicholls, N. Ranger, S. Hallegatte, J. Corfee-Morlot, C. Herweijer, and J. Chateau. 2011. 'A Global Ranking of Port Cities with High Exposure to Climate Extremes'. Climatic Change, 104(1): 89-111. https://doi.org/10.1007/ s10584-010-9977-4

Heynen, N. 2014. 'Urban Political Ecology I: The Urban Century'. Progress in Human Geography, 38(4): 598-604. https://doi.org/10.1177/0309132513500443 
Jagtap, T.G. and Nagle, V.L., 2007. Response and Adaptability of Mangrove Habitats from the Indian Subcontinent to Changing Climate. AMBIO: A Journal of the Human Environment, 36(4): 328-334.

Joshi, P., 2019. 'Expert View: Poor Planning Destroying Lives and Property'. Daily News Analysis India, Mumbai, 8 July 2019.

Khan, T.M., D.A. Quadir, T.S, Murty, and M.A. Sarker. 2004. 'Seasonal and Interannual Sea Surface Temperature Variability in the Coastal Cities of Arabian Sea and Bay of Bengal'. Natural Hazards, 31(2): 549-560. https://doi.org/10.1023/B:NHAZ.0000023367.66009.1d

Kumar, H. 2019. '32 Dead as Worst Flooding in a Decade Hits Booming Mumbai'. The New York Times, New York, 02 July 2019.

Kumar, A., A.C. Pandey, and M.L. Khan. 2020. Urban Risk and Resilience to Climate Change and Natural Hazards: A Perspective from Million-Plus Cities on the Indian Subcontinent. Techniques for Disaster Risk Management and Mitigation, 33-46. DOI:10.1002/9781119359203.ch3

Larour, E., E.R. Ivins, and S. Adhikari. 2017. Should coastal planners have concern over where land ice is melting? Science Advances, 3(11): e1700537.

Mehta, L., S. Srivastava, H.N. Adam, S. Bose, U. Ghosh, and V.V. Kumar. 2019. 'Climate Change and Uncertainty from 'Above' and 'Below': Perspectives from India'. Regional Environmental Change 19(6): 1533-1547. https://doi.org/10.1007/s10113-019-01479-7

Mehta, S. 2004. Maximum City: Bombay Lost and Found. New York: Vintage.

NASA. 2015. 'GISS Surface Temperature Analysis (v4)'. Available at: https://data.giss. nasa.gov/gistemp/station_data/ (accessed on 9 November 2017)

O'Brien, K. and J. Barnett. 2013. 'Global Environmental Change and Human Security'. Annual Review of Environment and Resources, 38: 373-391. https://doi. org/10.1007/978-3-540-75977-5_24

O'Brien, K., S. Eriksen, L.P. Nygaard, and A.N.E. Schjolden. 2007. 'Why Different Interpretations of Vulnerability Matter in Climate Change Discourses'. Climate Policy, 7(1): 73-88.

Parthasarathy, D. 2018. 'Inequality, Uncertainty, and Vulnerability: Rethinking Governance from a Disaster Justice Perspective'. Environment and Planning E: Nature and Space, 1(3): 422-442. https://doi.org/10.1177\%2F2514848618802554

Perur, S. 2016. 'Story of Cities \#11: The Reclamation of Mumbai - from the Sea, and Its People?’. The Guardian, London, 30 March 2016.

Pramanik, M.K. 2017. 'Impacts of Predicted Sea Level Rise on Land Use/Land Cover Categories of the Adjacent Coastal Areas of Mumbai Megacity, India'. Environment, Development and Sustainability, 19: 1343-1366. https://doi.org/10.1007/ s10668-016-9804-9

Ranger, N., S. Hallegatte, S. Bhattacharya, M. Bachu, S. Priya, K. Dhore, F. Rafique, P. Mathur, N. Naville, F. Henriet, and C. Herweijer. 2011. 'An Assessment of the Potential Impact of Climate Change on Flood Risk in Mumbai'. Climatic Change, 104: 139-167. https://doi.org/10.1007/s10584-010-9979-2

Revi, A. 2005. 'Lessons from the Deluge: Priorities for Multi-Hazard Risk Mitigation'. Economic and Political Weekly, 40(36): 3911-3916.

Revi, A. 2008. 'Climate Change Risk: An Adaptation and Mitigation Agenda for Indian Cities'. Environment and Urbanization, 20(1): 207-229. https://doi.org/10.1177/09562478 08089157

Ribot, J. 2014. 'Cause and Response: Vulnerability and Climate in the Anthropocene'. Journal of Peasant Studies, 41(5): 667-705. https://doi.org/10.1080/03066150.2014.894911

Singh, C., M. Madhavan, J. Arvind, and A. Bazaz. 2021. 'Climate Change Adaptation in Indian Cities: A Review of Existing Actions and Spaces for Triple Wins'. Urban Climate, 36: 100783. https://doi.org/10.1016/j.uclim.2021.100783 
Singh, L. 2020. '140-Year-Old Drainage System, Highest Rain Since '74 - Why South Mumbai Flooded'. The Indian Express, Mumbai, 7 August 2020.

Singhi, V. 2015. 'Despite Court Orders, Mumbai and Nearby Areas Lost 15-20\% Mangroves, Wetlands in 5 Years'. The Times of India, Haryana, 11 November 2015.

The Energy Research Institute (TERI). 2014. Assessing Climate Change Vulnerability and Adaptation Strategies for Maharashtra: Maharashtra State Adaptation Action Plan on Climate Change (MSAAPC). New Delhi: The Energy and Resources Institute.

Thomas, T., 2018. 'Mumbai Needs About \$220 Billion for City Infrastructure over 20 Years: Report'. The Live Mint, New Delhi, 25 June 2018.

UNEP, 2014. The Adaptation Gap Report 2014. Nairobi: United Nations Environment Programme (UNEP).

Van der Sluijs, J. 2005. 'Uncertainty as a Monster in the Science-Policy Interface: Four Coping Strategies'. Water Science and Technology, 52(6): 87-92.

Vijay, V., R.S. Biradar, A.B. Inamdar, G. Deshmukhe, S. Baji, and M. Pikle. 2005. 'Mangrove Mapping and Change Detection around Mumbai (Bombay) Using Remotely Sensed Data'. Indian Journal of Marine Sciences, 34(3): 310-315.

Vivekanandan, E., 2011. Marine Fisheries Policy Brief-3; Climate Change and Indian Marine Fisheries. CMFRI special publication, 105: 1-97.

Walker, W. E., P. Harremoës, J. Rotmans, J.P. Van Der Sluijs, M.B. Van Asselt, P. Janssen, and M.P. Krayer von Krauss. 2003. 'Defining Uncertainty: A Conceptual Basis for Uncertainty Management in Model-Based Decision Support'. Integrated Assessment, 4(1): 5-17. https://doi.org/10.1076/iaij.4.1.5.16466

Watson, V. 2009. 'Seeing from the South: Refocusing Urban Planning on the Globe's Central Urban Issues'. Urban Studies, 46(11): 2259-2275. https://doi. org/10.1177\%2F0042098009342598

While, A. and M. Whitehead. 2013. 'Cities, Urbanisation and Climate Change'. Urban Studies, 50(7): 1325-1331. https://doi.org/10.1177\%2F0042098013480963

Woetzel, J., D. Pinner, H. Samandari, H. Engel, M. Krishnan, B. Boland, and C. Powis. 2020. Climate Risk and Response: Physical Hazards and Socioeconomic Impacts. London: McKinsey Global Institute.

Zeiderman, A., S.A. Kaker, J. Silver, and A. Wood. 2015. 'Uncertainty and Urban Life'. Public Culture, 27(2): 281-304. http://dx.doi.org/10.1215/08992363-2841868 